Research Paper

\title{
Correlation of Chitinase 3-Like 1 Single Nucleotide Polymorphisms with Hepatocellular Carcinoma in Taiwan
}

Wayne Shih-Wei Huang1,\#, Hung-Yu Lin',3,4,5\#, Chao-Bin Yeh33,6, Li-You Chen7, Ying-Erh Chou 3,8 , Shun-Fa Yang 2,8, Yu-Fan Liu $9,10, \bowtie$

1. Department of Surgery, Show Chwan Memorial Hospital, Changhua, Taiwan

2. Institute of Medicine, Chung Shan Medical University, Taichung, Taiwan

3. School of Medicine, Chung Shan Medical University, Taichung, Taiwan

4. Department of Ophthalmology, Show Chwan Memorial Hospital, Changhua, Taiwan

5. Department of Optometry, Yuan Pei University, Hsinchu, Taiwan

6. Department of Emergency Medicine, Chung Shan Medical University Hospital, Taichung, Taiwan

7. Department of Anatomy, Faculty of Medicine, Chung Shan Medical University, Taichung, Taiwan

8. Department of Medical Research, Chung Shan Medical University Hospital, Taichung, Taiwan

9. Department of Biomedical Sciences, College of Medicine Sciences and Technology, Chung Shan Medical University, Taichung, Taiwan

10. Division of Allergy, Department of Pediatrics, Chung-Shan Medical University Hospital, Taichung, Taiwan

\# These authors contributed equally to the work.

$\triangle$ Corresponding author: Yu-Fan Liu, Ph.D., Department of Biomedical Sciences, College of Medicine Sciences and Technology, Chung Shan Medical University, 110 Sec. 1, Chien-Kuo N. Road, Taichung 40201, Taiwan. Telephone: +886-4-24730022 ext. 11819; Fax: +886-4-24751101. E-mail: yfliu@csmu.edu.tw

(C) Ivyspring International Publisher. This is an open access article distributed under the terms of the Creative Commons Attribution (CC BY-NC) license (https://creativecommons.org/licenses/by-nc/4.0/). See http://ivyspring.com/terms for full terms and conditions.

Received: 2016.09.29; Accepted: 2016.12.28; Published: 2017.02.07

\begin{abstract}
Hepatocellular carcinoma ( $\mathrm{HCC}$ ) is the second leading cause of cancer death in Taiwan. Multiple risk factors, such as chronic hepatitis $\mathrm{B}$ or $\mathrm{C}$ virus infection, carcinogen exposure, cirrhosis, and various single-nucleotide polymorphisms (SNPs), are considered to contribute to hepatocarcinogenesis. Chitinase-3-like protein 1 ( $\mathrm{CHI} 3 \mathrm{~L} 1)$, a biomarker implicated in inflammation and tissue remodeling, plays a promoting role in angiogenesis, antiapoptosis, and cell proliferation. This study investigated the role of CHI3LI SNPs in HCC susceptibility and clinicopathology. Real-time polymerase chain reaction was used to analyze four SNPs of CHI3LI in 343 patients with $\mathrm{HCC}$ and 686 cancer-free controls. We found associations with HCC susceptibility in CHI3LI rs880633 polymorphism carriers with genotypes $(T C+C C)$. We observed that $\mathrm{HCC}$ patients had lower frequencies of $\mathrm{CHI3LI}$ rs 6691378 polymorphisms with the variant genotype GA+AA than the wild-type carriers with distant metastasis and positive $\mathrm{HBsAg}$ did. In $200 \mathrm{HBsAg}$ negative HCC patients, we observed that the CHI3LI rs4950928 polymorphisms carriers with the variant genotype CG+GG had higher frequencies of vascular invasion. Finally, carriers of $\mathrm{CHI} 3 \mathrm{LI}$ rs6691378 and 10399805 polymorphisms with the variant genotypes GA+AA showed lower levels of alpha-fetoprotein in $\mathrm{HCC}$ laboratory status. In conclusion, our results indicate that patients with CHI3LI rs 880633 variant genotypes $\mathrm{TC}+\mathrm{CC}$ are at a higher risk of $\mathrm{HCC}$. CHI3LI polymorphisms rs880633 or rs 4950928 may be potential candidates for predicting poor HCC prognosis and clinical status.
\end{abstract}

Key words: Single nucleotide polymorphism, CHI3L1, Hepatocellular carcinoma

\section{Introduction}

Hepatocellular carcinoma (HCC) is the third most common cause of cancer-related mortality and the fifth most common cancer worldwide $[1,2]$. In
Taiwan, HCC is the second leading cause of cancer-related death [3]. Chitinase 3-like 1 (CHI3L1), also known as YKL-40 and human cartilage 
glycoprotein 39 , is a secreted $40-\mathrm{kD}$ mammalian glycoprotein encoded by the chitinase 3-like 1 gene located on human chromosome 1q32.1 [4]. CHI3L1 is a nonspecific inflammatory biomarker of disease and is secreted by activated macrophages and neutrophils in various tissues exhibiting inflammation, arthritic chondrocytes, cancer cells and vascular smooth muscle cells [5-11]. Because CHI3L1 is expressed and secreted by activated neutrophils and macrophages, previous studies have indicated that CHI3L1 may play an essential role in the inflammatory processes of tumors, such as stimulating angiogenesis and the remodeling of the extracellular matrix [7, 12-14]. High expression of CHI3L1 has been shown to be closely connected with the recurrence and metastasis of various human tumors such as breast cancer, nonsmall cell lung cancer, glioblastoma, and gastric cancer [15-20]. In addition, pretreatment levels of CHI3L1 were reported to be elevated in cervical cancer [21]. Recently, CHI3L1 was shown to correlate positively with p-Akt cell signaling but negatively with E-cadherin expression in HCC [22], and serum CHI3L1 was shown to be an independent prognostic factor for overall and recurrence-free survival in HCC patients receiving curative resection, indicating that elevated serum CHI3L1 levels predict poor prognosis in HCC after surgery [23].

Single-nucleotide polymorphisms (SNPs) are the most common type of DNA sequence variation, and may affect the expression of specific genes [24, 25]. SNPs in the CHI3L1 promoter region have been associated with elevated serum CHI3L1 levels and a higher risk of schizophrenia [26, 27], differential gene expression [27], and elevated transcript levels [28]. Elevated circulating CHI3L1 levels might be a biomarker for asthma and declining lung function [29]. Moreover, elevated serum CHI3L1 levels and CHI3L1 overexpression are found in and linked to liver injury, advanced liver fibrosis, and poor prognosis in HCC $[22,23,30]$. Zhu et al. also found that serum CHI3L1 level was an independent prognostic biomarker in HCC patients after transcatheter arterial chemoembolization [31]. However, the connection between CHI3L1 SNP expression and HCC regulation is not well established. Determining the mechanism of CHI3L1 regulation and expression in HCC requires information on the genetic variant of CHI3L1 SNPs involved in hepatocarcinogenesis. We performed a case-control study involving four CHI3L1 SNPs located in the promoter region and exon 5 to analyze the contribution of these polymorphisms of CHI3L1 to susceptibility to HCC and its pathological development.

\section{Materials and methods}

\section{Study subjects}

In this study, we recruited 343 patients with HCC between 2012 and 2016 at the Chung Shan Medical University Hospital, Taiwan. The 686 control groups were recruited at the same hospital without previous cancer history. The diagnoses of HCC were confirmed histologically in all cases. Demographic characteristics and medical information of the patients, including TNM staging, tumor size, lymph-node metastasis, vascular invasion, distant metastasis, presence of HBV surface antigen (HBsAg) and liver cirrhosis, were obtained from their medical records. The blood samples which obtained from the controls and HCC patients were stored in EDTA tubes, centrifuged immediately and stored at $-80^{\circ} \mathrm{C}$. The Institutional Review Board of Chung Shan Medical University Hospital approved this study (CSMUH No: CS15099), and informed written consent was obtained from each participant.

\section{Selection of chitinase 3-like 1 gene polymorphisms}

Three SNPs rs6691378 (-1371, C/T), rs10399805 $(-247, \mathrm{C} / \mathrm{T})$, and rs4950928 (-131, G/C) in the promoter region and SNP rs880633 (+2950, T/C) in exon 5 were selected based on the Chinese HapMap (Han Chinese in Beijing, China) data. The SNPs rs6691378, rs10399805 and rs4950928 in the promoter region of the CHI3L1 gene exhibit strong association of schizophrenia and the SNP rs4950928 G $\rightarrow$ C transversion impairs the MYC/MAX-regulated transcriptional activity [27]. SNP rs10399805 has been reported to disrupt the C/EBP-AML-1 binding site in the gene promoter and is predicted to increase CHI3L1 expression [32]. The CHI3L1 SNPs rs6691378 and rs10399805 and CHI3L1 haplotypes all correlated with the development of cervical pre-cancerous lesions and invasive cancer [33]. The rs880633 was found to modulate age-adjusted lung function in CF patients. The minor allele frequencies (MAFs) of these SNPs were $\geqq 5 \%$.

\section{DNA extraction and Single nucleotide polymorphisms genotyping}

Genomic DNA was extracted using QIAamp DNA blood mini kits (Qiagen, Valencia, USA) according to the manufacturer's instructions as described previously [34]. The final DNA prepared was stored at $-20^{\circ} \mathrm{C}$ and used as templates for the following experiments. Allelic discrimination of the rs880633 (+2950, T/C), $\operatorname{rs6691378~(-1371,~G/A),~}$ rs4950928 (-131, C/G) and $\operatorname{rs10399805~(-247,~G/A)~}$ polymorphisms was analyzed and asscessed by using 
ABI StepOne Real-Time PCR system (Applied Biosystems, Foster City, CA, USA). The final volume for each reaction mixture was $5 \mu \mathrm{L}$, containing $2.5 \mu \mathrm{L}$ TaqMan genotyping master mix, $0.125 \mu \mathrm{L}$ TaqMan probe mix, and $10 \mathrm{ng}$ genomic DNA. The reaction conditions included an initial denaturation step at 95 ${ }^{\circ} \mathrm{C}$ for $10 \mathrm{~min}$ followed by 40 cycles at $95^{\circ} \mathrm{C}$ for $15 \mathrm{~s}$ and $60^{\circ} \mathrm{C}$ for $1 \mathrm{~min}$ as described previously $[33,35]$.

\section{Statistical analysis}

The distributions of demographic characteristics and genotype frequencies for different genotypes between the HCC group and control group were analyzed using the chi-square test for categories of variables. The odds ratios (ORs) and their 95\% confidence intervals (CIs) of the association between the genotype frequencies and HCC were estimated using multiple logistic regression models by controlling for covariates. A $p$ value of less than 0.05 was considered statistically significant. The data were analyzed using SPSS 12.0 statistical software.

\section{Results}

Table 1 shows the statistical analysis of the demographic characteristics and clinical parameters. The 686 controls and 343 patients with HCC showed significant differences in their level of alcohol consumption $(\mathrm{p}<0.001)($ Table 1$)$.

Table 1. The distributions of demographical characteristics and clinical parameters in 686 controls and 343 patients with HCC.

\begin{tabular}{|c|c|c|c|}
\hline Variable & Controls $(\mathrm{N}=686)$ & Patients (N=343) & p value \\
\hline Age (yrs) & $\begin{array}{l}\text { Mean } \pm \text { S.D. } \\
62.11 \pm 4.33\end{array}$ & $\begin{array}{l}\text { Mean } \pm \text { S.D. } \\
62.92 \pm 11.67\end{array}$ & $\mathrm{p}=0.109$ \\
\hline Gender & n (\%) & n (\%) & \\
\hline Male & $490(71.4 \%)$ & $245(71.4 \%)$ & $\mathrm{p}=1.000$ \\
\hline Female & $196(28.6 \%)$ & $98(28.6 \%)$ & \\
\hline \multicolumn{4}{|c|}{ Alcohol consumption } \\
\hline No & $579(84.4 \%)$ & $218(63.6 \%)$ & $\mathrm{p}<0.001$ \\
\hline Yes & $107(15.6 \%)$ & $125(36.4 \%)$ & \\
\hline \multicolumn{4}{|c|}{ Tobacco consumption } \\
\hline No & $425(62.0 \%)$ & $205(59.8 \%)$ & $\mathrm{p}=0.497$ \\
\hline Yes & $261(38.0 \%)$ & $138(40.2 \%)$ & \\
\hline \multicolumn{4}{|l|}{ Stage } \\
\hline $\mathrm{I}+\mathrm{II}$ & & $224(65.3 \%)$ & \\
\hline III+IV & & $119(34.7 \%)$ & \\
\hline \multicolumn{4}{|c|}{ Tumor T status } \\
\hline$\leq \mathrm{T} 2$ & & $228(66.5 \%)$ & \\
\hline$>\mathrm{T} 2$ & & $115(33.5 \%)$ & \\
\hline \multicolumn{4}{|c|}{ Lymph node status } \\
\hline No & & $331(96.5 \%)$ & \\
\hline $\mathrm{N} 1+\mathrm{N} 2$ & & $12(3.5 \%)$ & \\
\hline \multicolumn{4}{|l|}{ Metastasis } \\
\hline M0 & & $325(94.8 \%)$ & \\
\hline M1 & & $18(5.2 \%)$ & \\
\hline \multicolumn{4}{|c|}{ vascular invasion } \\
\hline No & & $282(82.2 \%)$ & \\
\hline Yes & & $61(17.8 \%)$ & \\
\hline
\end{tabular}

Mann-Whitney U test was used between controls and patients with HCC.
Genotype distributions and associations between HCC and CHI3L1 gene polymorphisms are shown in Table 2. The alleles with the highest distribution frequency for rs6691378, rs10399805, rs4950928, and rs880633 genes of CHI3L1 in both the controls and HCC patients were homozygous for $G / G, G / G$ and $\mathrm{C} / \mathrm{C}$ and heterozygous for $\mathrm{T} / \mathrm{C}$. After the adjustment of several variables, we found that people with the rs6691378, rs10399805, and rs4950928 polymorphisms of the CHI3L1 gene did not have a significantly increased risk of HCC relative to wild-type (WT) carriers (Table 2). However, subjects with the CHI3L1 polymorphic rs880633 TC $+\mathrm{CC}$ genotypes exhibited significantly $(\mathrm{p}<0.05)$ higher risks (odds ratio $[\mathrm{OR}]=$ $1.32995 \% \mathrm{CI}=1.009-1.750)$ of HCC than did their corresponding WT homozygous subjects (Table 2).

Table 2. Distribution frequency of $\mathrm{CHI} 3 \mathrm{LI}$ genotypes in 686 controls and 343 patients with HCC.

\begin{tabular}{lllll}
\hline Variable & $\begin{array}{l}\text { Controls } \\
(\mathbf{N}=686) \mathbf{n}(\mathbf{0})\end{array}$ & $\begin{array}{l}\text { Patients } \\
\mathbf{( N = 3 4 3 )} \mathbf{n}(\mathbf{0})\end{array}$ & OR (95\% CI) & AOR (95\% CI) \\
\hline rs6691378 & & & & \\
GG & $321(46.8 \%)$ & $159(46.4 \%)$ & 1.00 & 1.00 \\
GA & $296(43.1 \%)$ & $151(44.0 \%)$ & $1.030(0.784-1.353)$ & $1.039(0.784-1.376)$ \\
AA & $69(10.1 \%)$ & $33(9.6 \%)$ & $0.966(0.612-1.524)$ & $1.008(0.631-1.610)$ \\
GA+AA & $365(53.2 \%)$ & $184(53.6 \%)$ & $1.018(0.785-1.320)$ & $1.033(0.790-1.350)$ \\
rs10399805 & & & & \\
GG & $335(48.8 \%)$ & $165(48.1 \%)$ & 1.00 & 1.00 \\
GA & $289(42.1 \%)$ & $153(44.6 \%)$ & $1.075(0.820-1.409)$ & $1.111(0.841-1.467)$ \\
AA & $62(9.0 \%)$ & $25(7.3 \%)$ & $0.819(0.496-1.350)$ & $0.899(0.538-1.501)$ \\
GA+AA & $351(51.2 \%)$ & $178(51.9 \%)$ & $1.030(0.794-1.334)$ & $1.074(0.822-1.403)$ \\
rs4950928 & & & & 1.00 \\
CC & $509(74.2 \%)$ & $245(71.4 \%)$ & 1.00 & $1.182(0.870-1.607)$ \\
CG & $160(23.3 \%)$ & $92(26.8 \%)$ & $1.195(0.886-1.610)$ \\
GG & $17(2.5 \%)$ & $6(1.8 \%)$ & $0.733(0.286-1.883)$ & $0.724(0.275-1.908)$ \\
CC+CG & $177(25.8 \%)$ & $98(28.6 \%)$ & $1.150(0.861-1.537)$ & $1.138(0.845-1.534)$ \\
rs880633 & & & & 1.00 \\
TT & $290(42.3 \%)$ & $122(35.6 \%)$ & 1.00 & $1.303(0.976-1.740)$ \\
TC & $315(45.9 \%)$ & $174(50.7 \%)$ & $1.313(0.991-1.739)$ \\
CC & $81(11.8 \%)$ & $47(13.7 \%)$ & $1.379(0.909-2.093)$ & $1.432(0.933-2.198)$ \\
TC+CC & $396(57.7 \%)$ & $221(64.4 \%)$ & $1.327(1.015-1.734)^{*} 1.329(1.009-1.750)^{*}$
\end{tabular}

The odds ratios (ORs) and with their $95 \%$ confidence intervals (CIs) were estimated by logistic regression models. The adjusted odds ratios (AORs) with their $95 \%$ confidence intervals (CIs) were estimated by multiple logistic regression models after controlling for alcohol consumption. * $\mathrm{p}$ value $<0.05$ as statistically significant.

By estimating the distribution frequency of clinical statuses and CHI3L1 genotype frequencies in the HCC patients, we clarified the role of CHI3L1 gene polymorphisms in HCC clinicopathologic statuses such as clinical stage (tumor, node, metastasis), tumor size, lymph node metastasis, distant metastasis, vascular invasion, Child-Pugh score, HBsAg, antihepatitis $\mathrm{C}$ virus (anti-HCV), and liver cirrhosis. No significant associations of rs10399805, rs4950928, and rs880633 gene polymorphisms with clinicopathologic statuses were observed (Data not shown). However, among the 343 HCC patients, those with the GA+AA polymorphic rs6691378 gene had a lower risk of distant metastasis $(\mathrm{OR}=0.314 ; 95 \% \mathrm{CI}=$ 
0.109-0.900, $\mathrm{p}=0.024)$ and a lower level of positive HBsAg (OR $=0.567 ; 95 \% \mathrm{CI}=0.368-0.875, \mathrm{p}=0.010)$ than the patients with rs6691378 WT did; however, no difference was found regarding the clinical stage, tumor size, lymph node metastasis, vascular invasion, Child-Pugh score, anti-HCV, and liver cirrhosis (Table 3). Moreover, in $200 \mathrm{HBsAg-negative} \mathrm{HCC}$ patients, we observed that those showing the CHI3L1 rs4950928 genetic variant CG+GG had a higher risk of vascular invasion $(\mathrm{OR}=2.710 ; 95 \% \mathrm{CI}=1.267-5.796, \mathrm{p}$ $=0.009$ ) relative to those showing the rs4950928 WT; no difference was observed regarding the clinical stage, tumor size, lymph node metastasis, Child-Pugh score, anti-HCV, and liver cirrhosis (Table 4).

Table 3. Odds ratio (OR) and $95 \%$ confidence interval $(\mathrm{Cl})$ of clinical status and $\mathrm{CHI} 3 \mathrm{LI}$ rs6691378 genotypic frequencies in 343 HCC patients.

\begin{tabular}{|c|c|c|c|c|}
\hline \multirow[t]{2}{*}{ Variable } & \multicolumn{2}{|c|}{ Genotypic frequencies } & \multirow[b]{2}{*}{ OR $(95 \%$ CI) } & \multirow[b]{2}{*}{ p value } \\
\hline & $\begin{array}{l}\text { GG } \\
(N=159)\end{array}$ & $\begin{array}{l}\text { GA+AA } \\
(N=184)\end{array}$ & & \\
\hline \multicolumn{5}{|c|}{ Clinical Stage } \\
\hline Stage I/II & $100(62.9 \%)$ & $124(67.4 \%)$ & 1.00 & $\mathrm{p}=0.383$ \\
\hline Stage III/IV & $59(37.1 \%)$ & $60(32.6 \%)$ & $0.820(0.525-1.281)$ & \\
\hline \multicolumn{5}{|l|}{ Tumor size } \\
\hline$\leqq \mathrm{T} 2$ & $104(65.4 \%)$ & $124(67.4 \%)$ & 1.00 & $\mathrm{p}=0.698$ \\
\hline$>\mathrm{T} 2$ & $55(34.6 \%)$ & $60(32.6 \%)$ & $0.915(0.584-1.434)$ & \\
\hline \multicolumn{5}{|l|}{$\begin{array}{l}\text { Lymph node } \\
\text { metastasis }\end{array}$} \\
\hline No & $154(96.9 \%)$ & $177(96.2 \%)$ & 1.00 & $\mathrm{p}=0.740$ \\
\hline Yes & $5(3.1 \%)$ & $7(3.8 \%)$ & $1.218(0.379-3.916)$ & \\
\hline \multicolumn{5}{|c|}{ Distant metastasis } \\
\hline No & $146(91.8 \%)$ & $71(97.3 \%)$ & 1.00 & $\mathrm{p}=0.024^{*}$ \\
\hline Yes & $13(8.2 \%)$ & $5(2.7 \%)$ & $0.314(0.109-0.900)$ & \\
\hline \multicolumn{5}{|c|}{ Vascular invasion } \\
\hline No & $132(83.0 \%)$ & $150(81.5 \%)$ & 1.00 & $\mathrm{p}=0.718$ \\
\hline Yes & $27(17.0 \%)$ & $34(18.5 \%)$ & $1.108(0.635-1.934)$ & \\
\hline \multicolumn{5}{|c|}{ Child-Pugh grade } \\
\hline A & $123(77.4 \%)$ & $138(75.0 \%)$ & 1.00 & $\mathrm{p}=0.610$ \\
\hline B or C & $36(22.6 \%)$ & $46(25.0 \%)$ & $1.139(0.691-1.876)$ & \\
\hline \multicolumn{5}{|l|}{ HBsAg } \\
\hline Negative & $81(50.9 \%)$ & $119(64.7 \%)$ & 1.00 & $\mathrm{p}=0.010^{*}$ \\
\hline Positive & $78(49.1 \%)$ & $65(35.3 \%)$ & $0.567(0.368-0.875)$ & \\
\hline \multicolumn{5}{|l|}{ Anti-HCV } \\
\hline Negative & $81(50.9 \%)$ & $98(53.3 \%)$ & 1.00 & $\mathrm{p}=0.668$ \\
\hline Positive & $78(49.1 \%)$ & $86(46.7 \%)$ & $0.911(0.596-1.394)$ & \\
\hline \multicolumn{5}{|c|}{ Liver cirrhosis } \\
\hline Negative & $33(20.8 \%)$ & $35(19.0 \%)$ & 1.00 & $\mathrm{p}=0.688$ \\
\hline Positive & $126(79.2 \%)$ & $149(81.0 \%)$ & 1.115 (0.655-1.897) & \\
\hline
\end{tabular}

Alpha-fetoprotein (AFP), aspartate aminotransferase, and alanine aminotransferase are common clinical pathological markers of HCC. We analyzed the levels of these pathological markers, which are associated with CHI3L1 genotypic frequencies, to clarify the relationship between the progression of clinical status and level of clinical pathological markers in HCC patients. Table 5 shows the association between the CHI3L1 genotypic

frequencies and HCC laboratory status; no significant association with the rs4950928 and rs880633 gene polymorphisms was observed. However, patients with the rs6691378 GA+AA ( $p=0.026)$ or rs10399805 $\mathrm{GA}+\mathrm{AA}(\mathrm{p}=0.047)$ genetic variant exhibited higher levels of AFP (Table 5) compared with those with the wild-type gene polymorphisms.

Table 4. Odds ratio (OR) and $95 \%$ confidence interval $(\mathrm{Cl})$ of clinical status and CHI3LI rs4950928 genotypic frequencies in 200 $\mathrm{HCC}$ patients with $\mathrm{HBsAg}$ negative status.

\begin{tabular}{|c|c|c|c|c|}
\hline \multirow[t]{2}{*}{ Variable } & \multicolumn{4}{|c|}{ Genotypic frequencies } \\
\hline & $\mathrm{CC}(\mathrm{N}=143)$ & CG+GG (N=57) & OR $(95 \% \mathrm{CI})$ & p value \\
\hline \multicolumn{5}{|c|}{ Clinical Stage } \\
\hline Stage I/II & $96(67.1 \%)$ & $40(70.2 \%)$ & 1.00 & $\mathrm{p}=0.677$ \\
\hline Stage III/IV & $47(32.9 \%)$ & $17(29.8 \%)$ & $0.868(0.446-1.690)$ & \\
\hline \multicolumn{5}{|l|}{ Tumor size } \\
\hline$\leqq \mathrm{T} 2$ & $97(67.8 \%)$ & $41(71.9 \%)$ & 1.00 & $\mathrm{p}=0.572$ \\
\hline$>\mathrm{T} 2$ & $46(32.2 \%)$ & $16(28.1 \%)$ & $0.823(0.419-1.618)$ & \\
\hline \multicolumn{5}{|l|}{$\begin{array}{l}\text { Lymph node } \\
\text { metastasis }\end{array}$} \\
\hline No & $137(95.8 \%)$ & $57(100 \%)$ & 1.00 & $\mathrm{p}=0.116$ \\
\hline Yes & $6(4.2 \%)$ & $0(0.0 \%)$ & --- & \\
\hline \multicolumn{5}{|c|}{ Distant metastasis } \\
\hline No & $138(96.5 \%)$ & $55(96.5 \%)$ & 1.00 & $\mathrm{p}=0.997$ \\
\hline Yes & $5(3.5 \%)$ & $2(3.5 \%)$ & $1.004(0.189-5.328)$ & \\
\hline \multicolumn{5}{|c|}{ Vascular invasion } \\
\hline No & $125(87.4 \%)$ & $41(71.9 \%)$ & 1.00 & $\mathrm{p}=0.009^{*}$ \\
\hline Yes & $18(12.6 \%)$ & $16(28.1 \%)$ & $2.710(1.267-5.796)$ & \\
\hline \multicolumn{5}{|c|}{ Child-Pugh grade } \\
\hline A & $113(79.0 \%)$ & $41(71.9 \%)$ & 1.00 & $\mathrm{p}=0.282$ \\
\hline B or C & $30(21.0 \%)$ & $16(28.1 \%)$ & $1.470(0.727-2.972)$ & \\
\hline \multicolumn{5}{|l|}{ Anti-HCV } \\
\hline Negative & $40(28.0 \%)$ & $17(29.8 \%)$ & 1.00 & $\mathrm{p}=0.793$ \\
\hline Positive & $103(72.0 \%)$ & $40(70.2 \%)$ & $0.914(0.465-1.794)$ & \\
\hline \multicolumn{5}{|l|}{ Liver cirrhosis } \\
\hline Negative & $36(25.2 \%)$ & $9(15.8 \%)$ & 1.00 & $\mathrm{p}=0.151$ \\
\hline Positive & $107(74.8 \%)$ & $48(84.2 \%)$ & $1.794(0.802-4.017)$ & \\
\hline
\end{tabular}

Table 5. Association of $\mathrm{CHI} L \mathrm{LI}$ genotypic frequencies with $\mathrm{HCC}$ laboratory status.

\begin{tabular}{lllll}
\hline Characteristic & $\begin{array}{l}\text { a-Fetoprotein } \\
\text { (ng/mL) }\end{array}$ & $\begin{array}{l}\text { AST } \\
\text { (IU/L) }\end{array}$ & $\begin{array}{l}\text { ALT } \\
\text { (IU/L) }\end{array}$ & $\begin{array}{l}\text { AST/ALT } \\
\text { ratio }^{\text {a }}\end{array}$ \\
\hline rs6691378 & & & & \\
GG & $5597.8 \pm 1780.4$ & $143.0 \pm 23.8$ & $124.6 \pm 19.6$ & $1.38 \pm 0.07$ \\
GA+AA & $1658.8 \pm 565.3$ & $130.9 \pm 20.7$ & $107.7 \pm 15.5$ & $1.57 \pm 0.13$ \\
p value & $0.026^{*}$ & 0.700 & 0.495 & 0.218 \\
rs10399805 & & & & \\
GG & $5307.3 \pm 1716.9$ & $140.6 \pm 23.0$ & $121.8 \pm 18.8$ & $1.38 \pm 0.07$ \\
GA+AA & $1795.3 \pm 588.1$ & $132.7 \pm 21.3$ & $109.7 \pm 16.1$ & $1.58 \pm 0.14$ \\
p value & $0.047^{*}$ & 0.800 & 0.625 & 0.211 \\
rs4950928 & & & & \\
CC & $3833.9 \pm 1089.8$ & $145.3 \pm 20.1$ & $114.4 \pm 13.4$ & $1.52 \pm 0.10$ \\
CG+GG & $2611.8 \pm 1472.4$ & $114.6 \pm 21.3$ & $118.2 \pm 27.2$ & $1.37 \pm 0.09$ \\
p value & 0.533 & 0.374 & 0.889 & 0.374 \\
rs880633 & & & & \\
TT & $1254.1 \pm 417.2$ & $101.2 \pm 14.7$ & $84.6 \pm 10.4$ & $1.48 \pm 0.10$ \\
TC+CC & $4716.2 \pm 1346.9$ & $156.0 \pm 22.8$ & $132.6 \pm 18.1$ & $1.49 \pm 0.11$ \\
p value & 0.061 & 0.093 & 0.061 & 0.938 \\
\hline $\begin{array}{l}\text { Mann-Whitney U test was used between two groups. } \\
\text { a Mean } \pm \text { S.E. }\end{array}$ \\
* p value < 0.05 as statistically significant. & & \\
& & & & \\
\hline
\end{tabular}




\section{Discussion}

This study provides novel information regarding the effects of CHI3L1 SNPs on HCC susceptibility and clinicopathology. Alcohol can cause progressive perivenous injury, impaired hepatocyte function, and endothelial cell pore loss [36, 37]. CHI3L1 serum levels have been shown to potentially provide prognostic information because they are elevated in alcoholic patients and are related to the presence of liver fibrosis [38]. We observed that alcohol consumption was more common in the HCC patients than in the controls (Table 1). CHI3L1 might secrete by hepatic stellate cells [39], which are believed to be the main effector cell in liver fibrogenesis [36, 37]. Elevated CHI3L1 levels have been found to be associated with an increased risk of liver fibrosis and to be involved in the activation of the innate immune system [40]. Thus, alcohol-consuming HCC patients may sustain high levels of baseline serum CHI3L1, thereby triggering liver fibrosis and cirrhosis.

The CHI3L1 SNP rs880633 is located in the promoter region exon 5 of the CHI3L1 gene. We found that CHI3L1 SNP rs880633 $\mathrm{TC}+\mathrm{CC}$ genetic variants occur more frequently in HCC patients than in controls (Table 2). The rs880633 polymorphism has been shown to modulate age-adjusted lung function in cystic fibrosis lung disease, and CHI3L1 might be a potential biomarker for this condition [41]. However, the detailed mechanism and influence of CHI3L1 rs880633 genetic variants have not been thoroughly investigated. The promoter SNP $-131 \mathrm{C} \rightarrow \mathrm{G}$ (rs4950928) in the CHI3L1 gene was found to be involved in CHI3L1 serum level modulation and asthmatic lung disease [29]; it is located in the core promoter of CHI3L1 within a binding site for MYC and MAX transcription factors. The minor allele (-131G on the forward strand) was found to disrupt binding and to be associated with lower messenger RNA levels in peripheral blood cells, reduced levels of circulating CHI3L1 protein, and, on the basis of a luciferase assay, reduced transcription [27]. However, in contrast to the findings of Ober et al., James et al. found that the rs4950928 CC genotype is associated with greater levels of circulating CHI3L1 [42]. Moreover, in a previous report, Abd El-Fattah et al. shown that CHI3L1 rs4950928 SNPs have no significant association with colorectal cancer [43]. In the present study, we found that the CHI3L1 rs4950928 CG+GG genotype carriers among the 200 HBsAg-negative HCC patients indicate a greater risk of vascular invasion $(p=0.009)$ (Table 4$)$. CHI3L1 has been identified as a promoter of angiogenesis in neoplasms and is involved in activation of the mitogen-activated protein kinase/extracellular signal-regulated kinase pathway in endothelial cells [44-46]. CHI3L1 has been shown to modulate vascular endothelial cell morphology and stimulate migration of endothelial cells by promoting the formation of branching tubules $[47,48]$. CHI3L1 may be involved in tumor angiogenesis. An in vivo study by Shao et al. found that CHI3L1 contributes to the growth of primary and metastatic tumors [49]. Our results are consistent with these findings in correlating CHI3L1 rs4950928 SNPs with malignancy and poor prognosis in HCC.

AFP, desgamma-carboxy prothrombin time, and AFP-leptin 3, have been identified as potential candidates for evaluating the prognosis of HCC patients [50]. However, these candidates are not always sufficient for the prediction of prognosis and recurrence in HCC [51]. In the present study, we found that HCC patients with rs6691378 GA+AA ( $\mathrm{p}=$ $0.026)$ or $r 10399805 \mathrm{GA}+\mathrm{AA}(\mathrm{p}=0.047)$ genetic variant have lower levels of AFP (Table 5). CHI3L1 levels in both healthy adults and in diseased patients have been found to be affected by CHI3L1 genetic variations [26, 29, 52, 53]. The rs10399805 SNP is located at position -247 and disrupts the C/EBP-AML-1 binding site in the gene promoter; it has been speculated that it increases CHI3L1 expression [32]. However, the rs10399805 polymorphism has been found to be associated with diseases such as atopy and schizophrenia [32, 54]. Regarding rs6691378 and rs10399805, the genetic contribution of CHI3L1 to schizophrenia has been shown to vary, despite it being mechanistically involved in the disease process [55]. In addition, our previous study demonstrated that the CHI3L1 SNPs rs6691378 and rs10399805 and the CHI3L1 haplotype correlate with the development of cervical precancerous lesions and invasive cancer [33]. The precise roles of rs6691378 and rs10399805 in CHI3L1 expression and regulation in HCC remain unclear. This may be a result of the variation and coordination of the regulation of different CHI3L1 polymorphisms in CHI3L1 serum levels.

In conclusion, our study shows that the SNPs of the CHI3L1 gene are potential tumor markers for HCC. Carriers of CHI3L1 genetic variants of rs880633 polymorphisms show various correlations with CHI3L1 modulation, HCC severity, and HCC prognosis. CHI3L1 may provide a marker for evaluating HCC prognosis.

\section{Acknowledgements}

This study was supported by a research grant from Chung Shan Medical University and Show Chwan Memorial Hospital (CSMU-SHOW-104-03). 


\section{Competing Interests}

The authors have declared that no competing interests exist.

\section{References}

[1] El-Serag HB. Hepatocellular carcinoma. N Engl J Med 2011; 365: 1118-1127.

[2] Parkin DM, Bray F, Ferlay J and Pisani P. Global cancer statistics, 2002. CA Cancer J Clin 2005; 55: 74-108.

[3] Weng CJ, Hsieh YH, Tsai CM, Chu YH, Ueng KC, Liu YF, Yeh YH, Su SC, Chen YC, Chen MK and Yang SF. Relationship of insulin-like growth factors system gene polymorphisms with the susceptibility and pathological development of hepatocellular carcinoma. Ann Surg Oncol 2010; 17: 1808-1815.

[4] Olaussen KA, Dunant A, Fouret P, Brambilla E, Andre F, Haddad V, Taranchon E, Filipits M, Pirker R, Popper HH, Stahel R, Sabatier L, Pignon JP, Tursz T, Le Chevalier T, Soria JC and Investigators IB. DNA repair by ERCC1 in non-small-cell lung cancer and cisplatin-based adjuvant chemotherapy. $\mathrm{N}$ Engl J Med 2006; 355: 983-991.

[5] Johansen JS. Studies on serum YKL-40 as a biomarker in diseases with inflammation, tissue remodelling, fibroses and cancer. Dan Med Bull 2006; 53: 172-209.

[6] Shackelton LM, Mann DM and Millis AJ. Identification of a 38-kDa heparin-binding glycoprotein (gp38k) in differentiating vascular smooth muscle cells as a member of a group of proteins associated with tissue remodeling. J Biol Chem 1995; 270: 13076-13083.

[7] Rehli M, Krause SW and Andreesen R. Molecular characterization of the gene for human cartilage gp-39 (CHI3L1), a member of the chitinase protein family and marker for late stages of macrophage differentiation. Genomics 1997; 43: $221-225$

[8] Harvey S, Weisman M, O'Dell J, Scott T, Krusemeier M, Visor J and Swindlehurst C. Chondrex: new marker of joint disease. Clin Chem 1998; 44: 509-516.

[9] Kzhyshkowska J, Mamidi S, Gratchev A, Kremmer E, Schmuttermaier C, Krusell L, Haus G, Utikal J, Schledzewski K, Scholtze J and Goerdt S. Novel stabilin-1 interacting chitinase-like protein (SI-CLP) is up-regulated in alternatively activated macrophages and secreted via lysosomal pathway. Blood 2006; 107: 3221-3228.

[10] Kzhyshkowska J, Gratchev A and Goerdt S. Human chitinases and chitinase-like proteins as indicators for inflammation and cancer. Biomark Insights 2007; 2: 128-146.

[11] Kzhyshkowska J and Krusell L. Cross-talk between endocytic clearance and secretion in macrophages. Immunobiology 2009; 214: 576-593.

[12] Volck B, Price PA, Johansen JS, Sorensen O, Benfield TL, Nielsen HJ, Calafat J and Borregaard N. YKL-40, a mammalian member of the chitinase family, is a matrix protein of specific granules in human neutrophils. Proc Assoc Am Physicians 1998; 110: 351-360.

[13] Renkema GH, Boot RG, Au FL, Donker-Koopman WE, Strijland A, Muijsers $\mathrm{AO}$, Hrebicek M and Aerts JM. Chitotriosidase, a chitinase, and the 39-kDa human cartilage glycoprotein, a chitin-binding lectin, are homologues of family 18 glycosyl hydrolases secreted by human macrophages. Eur J Biochem 1998; 251: 504-509.

[14] Rehli M, Niller HH, Ammon C, Langmann S, Schwarzfischer L, Andreesen R and Krause SW. Transcriptional regulation of CHI3L1, a marker gene for late stages of macrophage differentiation. J Biol Chem 2003; 278: 44058-44067.

[15] Shao R, Cao QJ, Arenas RB, Bigelow C, Bentley B and Yan W. Breast cancer expression of YKL-40 correlates with tumour grade, poor differentiation, and other cancer markers. Br J Cancer 2011; 105: 1203-1209.

[16] Johansen JS, Christensen IJ, Riisbro R, Greenall M, Han C, Price PA, Smith K, Brunner $\mathrm{N}$ and Harris AL. High serum YKL-40 levels in patients with primary breast cancer is related to short recurrence free survival. Breast Cancer Res Treat 2003; 80: 15-21.

[17] Choi IK, Kim YH, Kim JS and Seo JH. High serum YKL-40 is a poor prognostic marker in patients with advanced non-small cell lung cancer. Acta Oncol 2010; 49: 861-864.

[18] Thom I, Andritzky B, Schuch G, Burkholder I, Edler L, Johansen JS, Bokemeyer $\mathrm{C}$, Schumacher $\mathrm{U}$ and Laack E. Elevated pretreatment serum concentration of YKL-40-An independent prognostic biomarker for poor survival in patients with metastatic nonsmall cell lung cancer. Cancer 2010; 116: 4114-4121.

[19] Francescone RA, Scully S, Faibish M, Taylor SL, Oh D, Moral L, Yan W, Bentley B and Shao R. Role of YKL-40 in the angiogenesis, radioresistance, and progression of glioblastoma. J Biol Chem 2011; 286: 15332-15343.

[20] Bi J, Lau SH, Lv ZL, Xie D, Li W, Lai YR, Zhong JM, Wu HQ, Su Q, He YL, Zhan WH, Wen JM and Guan XY. Overexpression of YKL-40 is an independent prognostic marker in gastric cancer. Hum Pathol 2009; 40: 1790-1797.

[21] Mitsuhashi A, Matsui H, Usui H, Nagai Y, Tate S, Unno Y, Hirashiki K, Seki K and Shozu M. Serum YKL-40 as a marker for cervical adenocarcinoma. Ann Oncol 2009; 20: 71-77.

[22] Pan JJ, Ge YS, Xu GL, Jia WD, Liu WF, Li JS and Liu WB. The expression of chitinase 3-like 1: a novel prognostic predictor for hepatocellular carcinoma. J Cancer Res Clin Oncol 2013; 139: 1043-1054.
[23] Zhu CB, Chen LL, Tian JJ, Su L, Wang C, Gai ZT, Du WJ and Ma GL. Elevated serum YKL-40 level predicts poor prognosis in hepatocellular carcinoma after surgery. Ann Surg Oncol 2012; 19: 817-825.

[24] Morley M, Molony CM, Weber TM, Devlin JL, Ewens KG, Spielman RS and Cheung VG. Genetic analysis of genome-wide variation in human gene expression. Nature 2004; 430: 743-747.

[25] Sauna ZE, Kimchi-Sarfaty C, Ambudkar SV and Gottesman MM. Silent polymorphisms speak: how they affect pharmacogenomics and the treatment of cancer. Cancer Res 2007; 67: 9609-9612.

[26] Kruit A, Grutters JC, Ruven HJ, van Moorsel CC and van den Bosch JM. A CHI3L1 gene polymorphism is associated with serum levels of YKL-40, a novel sarcoidosis marker. Respir Med 2007; 101: 1563-1571.

[27] Zhao X, Tang R, Gao B, Shi Y, Zhou J, Guo S, Zhang J, Wang Y, Tang W, Meng J, Li S, Wang H, Ma G, Lin C, Xiao Y, Feng G, Lin Z, Zhu S, Xing Y, Sang H, St Clair D and He L. Functional variants in the promoter region of Chitinase 3-like 1 (CHI3L1) and susceptibility to schizophrenia. Am J Hum Genet 2007; 80: $12-18$.

[28] Dixon AL, Liang L, Moffatt MF, Chen W, Heath S, Wong KC, Taylor J, Burnett E, Gut I, Farrall M, Lathrop GM, Abecasis GR and Cookson WO. A genome-wide association study of global gene expression. Nat Genet 2007; 39: 1202-1207.

[29] Ober C, Tan Z, Sun Y, Possick JD, Pan L, Nicolae R, Radford S, Parry RR, Heinzmann A, Deichmann KA, Lester LA, Gern JE, Lemanske RF, Jr., Nicolae DL, Elias JA and Chupp GL. Effect of variation in CHI3L1 on serum YKL-40 level, risk of asthma, and lung function. N Engl J Med 2008; 358: 1682-1691.

[30] Tao H, Yang JJ, Shi KH, Huang C, Zhang L, Lv XW and Li J. The significance of YKL-40 protein in liver fibrosis. Inflamm Res 2014; 63: 249-254.

[31] Zhu CB, Wang C, Chen LL, Ma GL, Zhang SC, Su L, Tian JJ and Gai ZT. Serum YKL-40 independently predicts outcome after transcatheter arterial chemoembolization of hepatocellular carcinoma. PLoS One 2012; 7: e44648.

[32] Yang MS, Morris DW, Donohoe G, Kenny E, O'Dushalaine CT, Schwaiger S, Nangle JM, Clarke S, Scully P, Quinn J, Meagher D, Baldwin P, Crumlish N, O'Callaghan E, Waddington JL, Gill M and Corvin A. Chitinase-3-like 1 (CHI3L1) gene and schizophrenia: genetic association and a potential functional mechanism. Biol Psychiatry 2008; 64: 98-103.

[33] Lin YS, Liu YF, Chou YE, Yang SF, Chien MH, Wu CH, Chou CH, Cheng CW and Wang PH. Correlation of chitinase 3-like 1 single nucleotide polymorphisms and haplotypes with uterine cervical cancer in Taiwanese women. PLoS One 2014; 9: e104038.

[34] Cheng HL, Liu YF, Su CW, Su SC, Chen MK, Yang SF and Lin CW. Functional genetic variant in the Kozak sequence of WW domain-containing oxidoreductase (WWOX) gene is associated with oral cancer risk. Oncotarget 2016; 7: 69384-69396.

[35] Su SC, Hsieh MJ, Liu YF, Chou YE, Lin CW and Yang SF. ADAMTS14 Gene Polymorphism and Environmental Risk in the Development of Oral Cancer. PLoS One 2016; 11: e0159585.

[36] Friedman SL. Seminars in medicine of the Beth Israel Hospital, Boston. The cellular basis of hepatic fibrosis. Mechanisms and treatment strategies. N Engl J Med 1993; 328: 1828-1835.

[37] Friedman SL. Stellate cell activation in alcoholic fibrosis--an overview. Alcohol Clin Exp Res 1999; 23: 904-910.

[38] Nojgaard C, Johansen JS, Christensen E, Skovgaard LT, Price PA, Becker U and Group E. Serum levels of YKL-40 and PIIINP as prognostic markers in patients with alcoholic liver disease. J Hepatol 2003; 39: 179-186.

[39] Johansen JS, Christoffersen P, Moller S, Price PA, Henriksen JH, Garbarsch C and Bendtsen F. Serum YKL-40 is increased in patients with hepatic fibrosis. J Hepatol 2000; 32: 911-920.

[40] Puche JE, Saiman Y and Friedman SL. Hepatic stellate cells and liver fibrosis. Compr Physiol 2013; 3: 1473-1492.

[41] Hector A, Kormann MS, Mack I, Latzin P, Casaulta C, Kieninger E, Zhou Z, Yildirim AO, Bohla A, Rieber N, Kappler M, Koller B, Eber E, Eickmeier O, Zielen S, Eickelberg O, Griese M, Mall MA and Hartl D. The chitinase-like protein YKL-40 modulates cystic fibrosis lung disease. PLoS One 2011; 6: e24399.

[42] James AJ, Reinius LE, Verhoek M, Gomes A, Kupczyk M, Hammar U, Ono J, Ohta S, Izuhara K, Bel E, Kere J, Soderhall C, Dahlen B, Boot RG, Dahlen SE and Consortium B. Increased YKL-40 and Chitotriosidase in Asthma and Chronic Obstructive Pulmonary Disease. Am J Respir Crit Care Med 2016; 193: $131-142$

[43] Abd El-Fattah AA, Sadik NA, Shaker OG and Kamal AM. Are SMAD7 rs4939827 and CHI3L1 rs4950928 polymorphisms associated with colorectal cancer in Egyptian patients? Tumour Biol 2016; 37: 9387-9397.

[44] Areshkov PO, Avdieiev SS, Balynska OV, Leroith D and Kavsan VM. Two closely related human members of chitinase-like family, CHI3L1 and CHI3L2, activate ERK1/ 2 in 293 and U373 cells but have the different influence on cell proliferation. Int J Biol Sci 2012: 8: 39-48.

[45] Antonelli M, Massimino M, Morra I, Garre ML, Gardiman MP, Buttarelli FR, Arcella A and Giangaspero F. Expression of pERK and pAKT in pediatric high grade astrocytomas: correlation with YKL40 and prognostic significance. Neuropathology 2012; 32: 133-138.

[46] Pelloski CE, Lin E, Zhang L, Yung WK, Colman H, Liu JL, Woo SY, Heimberger AB, Suki D, Prados M, Chang S, Barker FG, 3rd, Fuller GN and Aldape KD. Prognostic associations of activated mitogen-activated protein kinase and Akt pathways in glioblastoma. Clin Cancer Res 2006; 12: 3935-3941. 
[47] Nishikawa KC and Millis AJ. gp38k (CHI3L1) is a novel adhesion and migration factor for vascular cells. Exp Cell Res 2003; 287: 79-87.

[48] Malinda KM, Ponce L, Kleinman HK, Shackelton LM and Millis AJ. Gp38k, a protein synthesized by vascular smooth muscle cells, stimulates directional migration of human umbilical vein endothelial cells. Exp Cell Res 1999; 250: 168-173.

[49] Shao R, Hamel K, Petersen L, Cao OJ, Arenas RB, Bigelow C, Bentley B and Yan W. YKL-40, a secreted glycoprotein, promotes tumor angiogenesis. Oncogene 2009; 28: 4456-4468.

[50] Baylin SB and Ohm JE. Epigenetic gene silencing in cancer - a mechanism for early oncogenic pathway addiction? Nat Rev Cancer 2006; 6: 107-116.

[51] Maheshwari S, Sarraj A, Kramer J and El-Serag HB. Oral contraception and the risk of hepatocellular carcinoma. J Hepatol 2007; 47: 506-513.

[52] Zheng JL, Lu L, Hu J, Zhang RY, Zhang Q, Chen QJ and Shen WF. Genetic polymorphisms in chitinase 3-like 1 (CHI3L1) are associated with circulating YKL-40 levels, but not with angiographic coronary artery disease in a Chinese population. Cytokine 2011; 54: 51-55.

[53] Lee H, Kang R, Jee SH and Yoon Y. A promoter polymorphism -2122C $>\mathrm{T}$ of CHI3L1 is associated with serum low density lipoprotein cholesterol level in Korean subjects. Clin Biochem 2010; 43: 1195-1200.

[54] Sohn MH, Lee JH, Kim KW, Kim SW, Lee SH, Kim KE, Kim KH, Lee CG, Elias JA and Lee MG. Genetic variation in the promoter region of chitinase 3-like 1 is associated with atopy. Am J Respir Crit Care Med 2009; 179: 449-456.

[55] Yamada K, Hattori E, Iwayama Y, Toyota T, Ohnishi T, Iwata Y, Tsuchiya KI, Sugihara G, Kikuchi M, Okazaki Y and Yoshikawa T. Failure to confirm genetic association of the CHI3L1 gene with schizophrenia in Japanese and Chinese populations. Am J Med Genet B Neuropsychiatr Genet 2009; 150B: $508-514$ 